\title{
КВАЛИТЕТ НА ЖИВОТ КАЈ ПАЦИЕНТИТЕ КОИ СЕ НА МЕДИКАМЕНТОЗЕН ТРЕТМАН ЗА БЕНИГНА ПРОСТАТИЧНА ХИПЕРПЛАЗИЈА
}

\author{
Маја Софрониевска-Главиновㄹ, Светлана Јовевска², МихаилКочубовски³ \\ Универзийейска клиника захируршки болесйи „Св.Наум Охрияски“, Скойје, Рейублика Северна \\ макеgонија \\ Факулиеиеи за меgицински науки, Универзитеей „Гоце Делчев“, Шйий, Рейублика Северна Макеgонија,

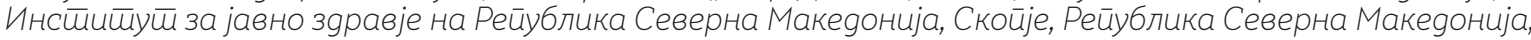

Цитирање: Софрониевска-Главинов М, Јовевска С, Кочубовски М. Квалитет на живот кај пациентите кои се на медикаментозен третман за бенигна простатична хиперплазија. Арх J Здравје 2019:11(1):89-94

Клучни зборови: бенигна простатична хиперплазија, симптоми, квалитет на живот

*Кореспонденција: Маја Софрониевска-Главинов, Универзитетска клиника за хируршки болести „в.Наум Охридски“ Скопје Република Северна Македонија. E-mail: msofronievska@ yahoo.com

Примено: 15-јан-2019; Ревидирано: 23-фев-2019; Прифатено: 28-фев-2019; Објавено: 15-мар-2019 Печатарски права: 2019 Маја Софрониев-

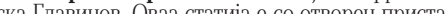

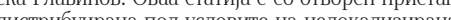
дистрибиран лиценца, која овозможува неограничена употреба, дистрибуција и репродукција на било ко медиум, доколку се цитираат оригиналниот(ите автор(и) и изворот.

Конкурентски интереси: Авторот изјавува дека

нема конкурентски интереси.

\section{Извадок}

Целта на ова истражување беше да се одреди влијанието на симптомите и ефектите од медикаментозниот третман врз квалитетот на живот на пациентите со бенигна простатична хиперплазија (БПХ). За таа цел направивме евалуација на две групи пациенти преку интернационален прашалник за скорирање на симптомите на долен уринарен тракт, Беков прашалник за депресија и прашање за квалитетот на животот. Првата (контролна) група ја сочинуваа пациенти со БПХ кои беа на терапија со алфаблокатор, додека вторатагрупа (испитувана) пациенти беа на комбинирана терапија со алфаблокатор и 5-алфа-редуктаза инхибитор. При анализа на резултатите дојдовме до заклучок дека пациентите во контролната група имаа подобар квалитет на живот како и психосоцијален статус кои се должат на послабо изразените симптоми на болеста. Пациентите во втората група имаа полош квалитет на живот заради појавата на несакани ефекти од терапијата со 5АРИ: еректилна дисфункција и депресија, како и заради потешко изразените симптоми. Модалитетите во терапевтскиот пристап овозможуваат подобрување на симптомите во втората група и подобрување на квалитетот на живот на пациентите со двојна терапија за БПХ.

\section{CLINICAL SCIENCE}

\section{QUALITY OF LIFE ASSESMENT IN PATIENTS TREATED WITH MEDICAMENTS FOR BENIGN PROSTATIC HYPERPLASIA}

\author{
Maja Sofronievska-Glavinov ${ }^{1}$, Svetlana Jovevska², Mihil Kocubovski ${ }^{3}$ \\ 1 University Clinic for Surgical Diseases „St. NaumOhridski“, Skopje, Republic of North Macedonia \\ Faculty of Medicine, University Goce Delcev, Stip, Republic of North Macedonia \\ Institute of Public Health, Skopje, Republic of North Macedonia
}

\begin{abstract}
Citation: Sofronievska-Glavinov M, Jovevska S, Kocubovski M. Quality of life assesment in patients treated with medicaments for benign prostatic hyperplasia Arch Pub Health 2019; 11 (1): 89-94 (Macedonian)

Key words: benign prostatic hyperplasia, symptoms, quality of life

*Correspondence: Maja Sofronievska-Glavinov, University Clinic for surgical diseases Ss. Naum Ohridski, Skopje, Republic of North Macedonia. E-mail:msofronievska@yahoo.com

Received: 15-Jan-2019; Revised: 23-Feb-2019; Accepted: 28-Feb-2019; Published: 15-Mar-2019 Copyright: ( ) 2019. Maja Sofronievska-Glavinov. This is an open-access article distributed under the terms of the Creative Commons Attribution License, which permits unrestricted use, distribu tion, and reproduction in any medium, provided the original author(s) and source are credited.

Competing Interests: The author have declared that no competing interests
\end{abstract}

\section{Abstract}

The purpose of this study was to determine the impact of symptoms and the effects of drug treatment on the quality of life in patients with benign prostatic hyperplasia. We evaluated two groups of patients with the International Prostate Scoring System questionnaire, the Beck depression inventory and an issue/question on quality of life. The first (control) group consisted of patients with benign prostatic hyperplasia who were on alpha-blocker therapy, while the second group of patients (examined) were on combination therapy with alpha blocker and 5-alpha reductase inhibitor. In analyzing the results, we came to the conclusion that patients in the control group had a better quality of life and psychosocial status due to the weaker symptoms of the disease. Patients in the second group had a poorer quality of life due to development of side effects of 5-alpha reductase inhibitors therapy: erectile dysfunction and depression. Modalities in the therapeutic approach enable improvement of the symptoms in the second group and improvement of the quality of life in patients with dual therapy for BPH. 


\section{Вовед}

Бенигна хиперплазија на простата (БПХ) е бенигно зголемувањена простатата кога доаѓ до прекумерен растна нормалните клетки (жлездените и/ или мускулните), и кое предизвикува симптоми на долниот уринарен тракт (СДУТ $)^{1}$.

Иако нема научна потврда за гените одговорни за настанување на БПХ, сепак фамилијарната анамнеза за БПХ и молекуларните абнормалности ја зголемуваат можноста за настанување на БПХ кај мажите. БПХ е најчесто бенигно заболување на простатата кое се јавува кај возрасната машка популација². Оваа „машка болест“ е најголема грижа на јавното здравство бидејќи има висока стапка на морбидитет со последователно влошување на квалитетот на животот на пациентите кои страдаат од ова заболување ${ }^{3}$.

Нормалната простата кај мажи на возраст помеѓ 21 и 30 години тежи 20грама. Преваленцијата на БПХ се зголемува со стареењето и на возраст од 80 години надминува $80 \% 4$.

Главните ризик-фактори за настанување на болеста се возраста и хормоните кои ги продуцира нормалниот тестис. Преваленцијата на БПХ во четвртата декада од животот е само 8\%, додека 50\% од мажите развиваат симптоми на болеста на возраст помеѓу 51 и 60 години. Мажите на возраст од 70 до 79 години имаат 4,6 пати поголема веројатност да побараат лекарска помош за симптомите поврзани со БПХ во однос на мажите од 40 до 49 години 5 .

Симптомите на долниот уринарен тракт кои се предизвикани од зголемувањето на волуменот на простатата се присутни кај 70\% од пациентите со БПХ

Прогресијата на БПХ се манифестира со зголемување на волуменот на простатата и намалување на максималниот уретрален проток (Qmax). Истовремено со прогедирање на симптомите се зголемува и ризикот од настанување на акутна уринарна ретенција, а со тоа и потребата за хируршки третман на БПХ. Одредувањето на прогресијата на болеста во клиничката пракса, освен со гореневедените мерења, се врши и со Меѓународен прашалник за ско- рирање на простатичните симптоми т.е. ИПСС (Интернационален простата скор систем). Раното препознавање на симптомите и раниот третман на пациентите со БПХ е од особена важност за одржување на квалитетот на живот на пациентите со БПХ. Најдобар начин за евалуација на БПХ по дијагностицирањето е со ИПСС прашалник?

Целта на ова истражување беше да се одреди влијанието на симптомите на болеста и ефектите од медикаментозниот третман врз квалитетот на живот на пациентите со БПХ. Исто така, со ова истражување ќе се добијат важни сознанија за влијанието на видот на медикаментите и времетраењето на терапијата врз нивното психосоцијално однесување и особено врз квалитетот на живот.

\section{Материјал и методи}

Оваа клиничка студија е работена според принципите на Хелсиншката декларација за пациентите и нивните права и е одобрена од институцијата во која работи првиот автор. Спроведовме рандомизирана контролирана проспективна фармако-епидемиолошка студија за евалуација на корелацијата на несаканите ефекти од употребата на 5-алфа-редуктаза инхибитори (5АРИ) кај мажи со бенигна простатична хиперплазија. Беше направена споредбена анализа на пациентите со БПХ на возраст од 45-70 години кои беана различни типови медикаментозен третман за БПХ, а беа распределени во две групи. Првата (контролна) група $(\mathrm{n}=56)$ беа пациенти со симптоми и дијагноза на БПХ и беа лекувани со монотерапија со алфа блокатор (тамсулозин). Втората (испитувана) група $(n=54)$ ја сочинуваа пациенти со симптоми и клинички знаци за БПХ и беана двојна терапија за БПХ т.е. алфа блокатор (тамсулозин) и 5-алфа-редуктаза инхибитор (5АРИ), дутастерид.

Евалуацијата на двете групи пациенти беше направена преку ИПСС прашалник, прашалник за Бекова депресија и прашање за квалитетот на животсодржано под реден број 8 во ИПСС прашалникот, со независна интерпретација.

Скорот добиен од ИПСС прашалникот 
ги класифицира во три групи пациентите со БПХ, и тоа: пациенти со лесни (1-7), средни (8-19) и тешки (20-35) симптоми. Според резултатите добиени од спроведениот ИПСС прашалник добивме број на пациенти кои имаа лесни, средни и тешки симптоми на долниот уринарен тракт предизвикани од БПХ, што е прикажано вотабелата бр.1.(Број на пациенти класифицирани според тежина на изразеност на симптомите на БПХ според ИПСС- ова претпоставувам треба да оди како наслов на табелата)

Терапијата кај пациентите со БПХ беше одредена во зависност од волуменот на простатата измерен со ехосонографија и нивото на простата-специфичен антиген (ПСА). На оние пациенти кои имаа простати со волумен помал од 40г и ПСА до 4нг/мл им беше одредена терапија со алфа блокатор. На пациентите со БПХ кои имаа големина на простата повеќе од 40г и ПСАдо 4нг/мл им беше одредена комбинирана терапија со алфа блокатор и 5-алфа-редуктаза инхибитор (дутастеруд).

Појавата на нарушување во расположението и квалитетот на живот беше одредена при првиот преглед кај уролог (нулта состојба), по 6 и по 12 месеци од одредување на медикаментозниот третман.

Квалитетот на животот кај пациентите го анализиравме преку осмото прашање од ИПСС прашалникот кое се градуира со оценка од 1 до 5, каде 1 означува задоволен пациент, 2 главно задоволен, 3 половина од времето задоволен, а половина незадоволен, 4 главно незадоволен и 5 несреќен пациент.

Нарушувањата во расположението ги евалуиравме преку спроведување на
Беков прашалник за депресија кој содржи 21 прашање и е предмет на самоевалуација на пациентите. Скорирањето и интерпретацијата на резултатите ја направи уролог, при што според скалата за БД беа класифицирани пациентите: нормални осцилации (1-10), умерени осцилации (11-16), гранична клиничка депресија (17-20), умерена депресија (21-30) и тешка депресија (31-40). Податоците кои ги добивме во текот на истражувањето беа внесени во база на податоции обработени со програмот Статистика7. Ги користевме методите на дескриптивна статистика, групна анализа и корелациони матрици.

\section{Резултати}

При првиот преглед на пациентите со БПХ кај уролог (нулто време), освен анализата на ИПСС и одредување на терапијата, беше одреден и квалитетот на животот кај овие пациенти кои беабез претходна анти БПХ терапија.

При анализа на резултатите заклучено е дека најголем дел од пациентите иницијално имаа квалитет на живот со оцена меѓу 2 и 4, што се должи на појако изразените симптоми на долниот уринарен тракт (графикон 1а). Во шестиот месец од медикаментозниот третман дојде до значително зголемување на бројот на пациентите со БПХ кои имаа квалитет на живот 2 т.е. се чувствуваа главно задоволни (графикон 16). По 12 месеци од терапијата се зголеми бројот на пациенти што се чувствуваа задоволно и тоа го оценија со оцена 1 , но исто така се зголеми и бројот на пациенти чиј квалитет на живот се влоши до оцена 5-несреќно (графикон 1в).
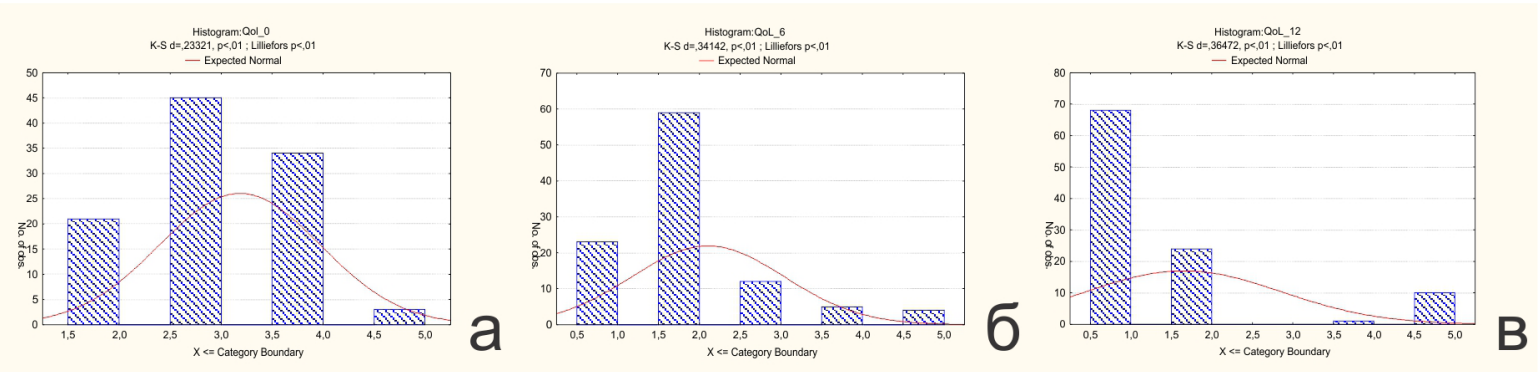

Графикон 1. Квалитет на живот кај пациентите со БПХ при: а) првиот преглед кај уролог(нулто време), 6) по 6 месеци терапија и в) по 12 месеци терапија 
Анализирајќи го квалитетот на живот одделно кај контролната и испитуваната група пациенти, дојдовме до заклучок дека во контролната група пациенти кои беа на терапија со алфа блокатор, веќе по 6-тиот месец настапи зголемување на бројот на пациенти кои имаа квалитет на живот оценет со 1 и 2 т.е.беа задоволни и главно задоволни (графикон 26, ознака М). Во 12-тиот месец, најголем број од пациентите беа задоволни и го оценија квалитетот на живот со 1 (графикон 2в, ознака М). Оваа група не пријави влошување на квалитетот на живот.

Во испитуваната група пациенти со БПХ, кои беа на двојна терапија со алфа блокатор и 5-алфа-редуктаза инхибитор, квалитетот на живот се подобри само кај некои пациенти по 6-тиот месец (графикон 26, ознака D), за во 12-тиот месец да се забележи подобрување до оцена 1 и 2 кај дел од пациентите, но и влошување до оцена 5-несреќен кај некоиод пациентите (графикон 2в, ознака D).

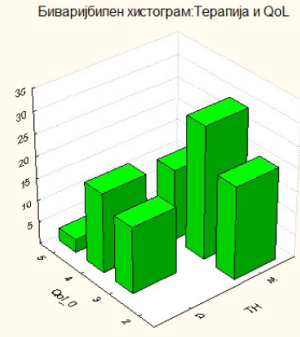

a

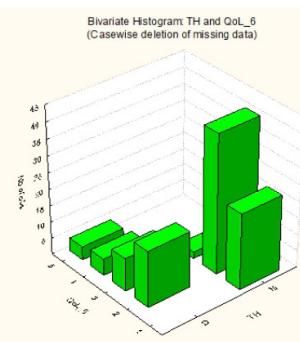

Графикон 2. Сооднос на квалитетот на живот кај пациентите во двете групи во а) нулта точка, 6) по 6 месеци терапија и в) по 12 месеци терапија

Истовремено резултатите покажаа дека појавата на Бекова депресија во значителна мерка корелираше со степенот на изразеност на СДУТ $(\mathrm{p}<0,05)$, скорирано со ИПСС. Како што е прикажано на графиконот За, при првиот преглед пациентите со повисок ИПСС скор покажале повисок индекс на депресија кој се движеше од
12 до 15 (умерени осцилации на расположението). По 6-тиот месец од терапијата, индексот на расположение главно се нормализира, но останаанекои пациентите кои сѐуште пројавувааумерени осцилации (графикон 36). Оваа појава се /забележа и 12-тиот месец од терапијата (графикон 3в).
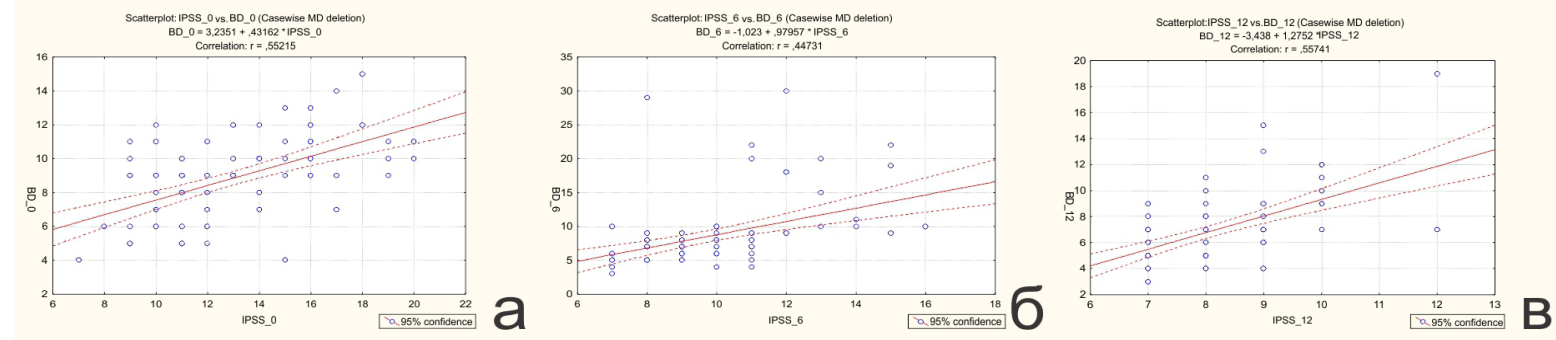

Графикон 3. Беков индекс за депресија кај пациентите со БПХ во корелација со јачина та на симптомите според ИПСС скала:а) во нулто време 6) по 6 месеци тера пија и в) по 12 месеци терапија

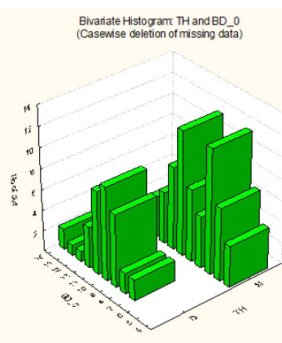

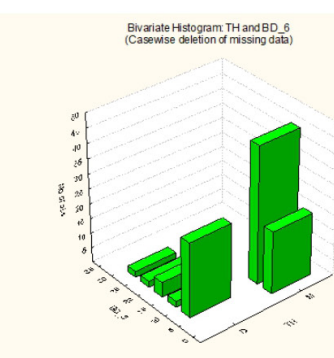

a

Графикон 4. Приказ на психолошкиот индекс кај пациентите во контролната група (M) и испитуваната група (D) во нулто време (a), по 6 месеци терапија (6) и по 12 месеци терапија (в) 
Како што е прикажано на графиконот 4, разноликоста во психолошката состојбакајпациентитевоконтролната група по 6 месеци терапија со алфа блокатор се стабилизира и во 12-тиот месец сите пациенти беа со стабилна психолошка состојба.

Во испитуваната група иницијално по 6-тиот месец имаше подобрување на психолошката состојба кај повеќето пациенти, но во 12-тиот месец сепојави група пациенти кои покажаа знаци за депресија.

\section{Дискусија}

Пациентите во контролната група заради тежината на симптомите, кои во најголема мера варираа помеѓу лесни и средно изразени, покажаа знаци на умерени осцилации во расположението и незадоволство во квалитетот на животот пред почнувањето на медикаментозниот третман. Ова се должи на потенцираните иритативни симптоми и особено ноктуријата која значително влијае врзквалитетот на животот за што веќе има одредени показатели во литературата $^{8}$.

Со воведување на алфа блокаторот во терапијата на БПХ, веќе во првите неколку недели дојде до подобрување на симптомите на БПХ, ноќното мочање/ уринирање се сведе на еднаш до ниеднаш, заради што пациентите имаат поквалитетен живот ${ }^{9}$. Истовремено се намали потребата за често уринирање и врзаноста со тоалет, така што пациентите можеа многу послободно да функционираат и да се социјализираат ${ }^{10}$.

Во нашето истражување пациентите во испитуваната група иницијално имааод средно до тешко изразени симптоми на долниот уринарен тракт. Заради ова, тиеимаа поголеми осцилации во расположението и кај поголем број од пациентите беше евидентно намалувањето на квалитетот на животот $(\mathrm{p}<0,05)$. Со воведување на 5-алфа-редуктаза инхибитор во комбинација со алфа блокаторот, иницијално заради алфа блокаторот настана подобрување на СДУТ $(\mathrm{p}<0,05)$, асо тоа и на квалитетот на животот. Кај дел од нив (15\%) настана влошување на квалитетот на живот заради појава на несакани ефекти или т.н. пост 5 АРИ синдром: еректилна дисфункција, депресивно расположение и намалено либидо. Појавата на овие несакани ефекти е опишана во литературата ${ }^{11}$.

Синдромот на 5 АРИ е предизвик и предмет на истражување во последните неколку години токму заради влијанието врз квалитетот на живот на пациентите кај кои се појавува. ${ }^{12}$ Имено, кај овие пациенти симптомите на БПХ се намалуваат по својот интензитет што само по себе би требало да го подобри и квалитетот на животот, но од друга страна заради појава на несаканите ефекти доаѓа до влошување на квалитетот на животот ${ }^{13}$.

Со цел да се одбегнат несаканите ефекти на 5АРИ и да се овозможи нивна континуирана употреба кај пациентите со БПХ, потребни се подлабоки истражувања во однос на механизмите на настанување на 5АРИ синдромот и механизмите на негово надминување.

\section{Заклучок}

Тежината на СДУТ има влијание врз психолошката состојба и квалитетот на животот на пациентите со БПХ. Брзото препознавање и третман на симптомите на БПХ овозможува намалување на депресивните состојби кај мажите кои страдаат од ова нарушување. Пациентите со БПХ кои примаат двојна терапија за БПХ треба да бидат будно следени заради можноста од појава на несакани ефекти во рамките на пост 5АРИ синдром, што дополнително може даја влоши нивната психолошка состојба, самодовербатаи негативно дасе одрази врзнивниот квалитетна живот.

Со редовно следење и препознавање на овие несакани појависе овозможува во терапијата да се воведат лекови кои ќе влијаат на еректилната функција (5-фосфодиестераза инхибитори или дехроандростерон) и истовремено ќе влијаат на подобрување на квалитетот на животот на пациентите кај кои се појавиле истите. 


\section{Референци:}

1. Trueman P, Hood SC, Nayak USL, Mrazeik MF. Prevalenceof lower urinary tract symptoms and self-reported diagnosed'benign prostatic hyperplasia', and their effect onquality of life in a community-based survey of men in theUK. BJU Int 1999;83:410-5.

2. Roehrborn CG. Benign Prostatic Hyperplasia: An Overview. Rev Urol 2005; 7:3-14.

3. BoschJL, HopWC, KirkelsWJ, Schröder FH. Natural history of benign prostatic hyperplasia: appropriate case definition and estimation of its prevalence in the community.Urology 1995; $46: 34-40$.

4. Berry SJ, Coffey DS, Walsh PC, Ewing LL. The development of human benign prostatic hyperplasia with age. J Urol 1984;132:474-479.

5. Sarma AV, Jacobson DJ, McGree ME, Roberts RO, LieberMM, Jacobsen SJ. A population based study of incidenceand treatment of benign prostatic hyperplasia amongresidents of Olmsted County, Minnesota: 1987 to 1997. J Urol 2005;173:2048-53.

6. Parsons JK, Bergstrom J, Silberstein J, Barrett-Connor E. Prevalence and characteristics of lower urinary tract symptoms in men aged $>$ or $=80$ years . Urology 2008;72:318-321

7. Browne CT, Emberton M. Self-management for men with lower urinary tract symptoms. Curr Urol Rep 2009;10:26167.

8. Barry MJ, Fowler FJ Jr, O'Leary MP, et al. The American Urological Association Symptom Index for benign prostatic hyperplasia. The Measurement Committee of the American Urological Association. J Urol 1992;148(5):1549-57

9. Chapple C, Abrams P, editors. Male lower urinary tract symptoms (LUTS). An international consultation. Montreal, Canada: International Consultation on Urological Diseases (ICUD); Societe Internationale d'Urologie;2013.

10. Brubaker L, Khullar V, Piault E, et al. Goal attainment scaling in patients with lower urinary tract symptoms: development and pilot testing of the Self-Assessment Goal Achievement (SAGA) questionnaire. Int Urogynecol J 2011; 22(8):937-46.

11. Liu L, Zhao S, Li F, Li E, Kang R, Luo $\mathrm{L}$, et al. Effect of 5 alphareductase inhibitors on sexual function: a meta-analysis and systematic review of randomized controlled trials. J Sex Med 2016;13(9):1297-310.

12. Traish AM, Hassani J, Guay AT, Zitzmann M, Hansen ML. Adverse side effects of 5 alpha-reductase inhibitors therapy: persistent diminished libido and erectile dysfunction and depression in a subset of patients. J SexMed 2011;8(3):872-84.

13. Kaplan SA, Chung DE, Lee RK, Scofield S, Te AE. A 5-year retrospective analysis of 5 alpha-reductase inhibitors in men with benign prostatic hyperplasia: finasteride has comparable urinary symptom efficacy and prostate volume reduction, but less sexual side effects and breast complications than dutasteride. Int J ClinPract 2012;66(11):1052-5. 